sulphoxide, but were stable and resistant to physical stress $(1,000 \mathrm{~g})$ after being frozen directly in liquid nitrogen. Recoveries of greater than 70 per cent have consistently been obtained from all salmonid species tested using 1 volume of 25 per cent dimethyl sulphoxide in CDS to 1 volume blood-CDS suspension, with aluminium foil packets as freezing containers and liquid nitrogen as the freezing agent. Unbuffered dimethyl sulphoxide solutions are acidic $(p \mathrm{H}$ about $5 \cdot 6)$ and unsuitable for preservation of trout and salmon erythrocytes. The slightly alkaline solution of dimethyl sulphoxide in CDS was found to be optimal for preservation of these cells.

In a number of tests, using rainbow trout iso-immune, carp immune, or rabbit immune antisera, the antigenic specificities of fish red blood cells frozen with dimethyl sulphoxide have been unchanged from those of unfrozen controls. Salmonid red cells were agglutinable when suspended in $12 \cdot 5$ per cent dimethyl sulphoxide solutions, but most of the blood typing has been performed after removal of the additive.

HAROLD O. HODGINS

U.S. Fish and Wildlife Service,

George J. Ringway

Bureau of Commercial Fisheries,

Biological Laboratory,

Seattle, Washington.

'Cushing, J. E., Amer. Naturalist, 96, 193 (1962).

${ }^{2}$ Ridgway, G. J., Amer. Naturalist, 96, 219 (1962).

Gibbs, M. B., McCord, E. B., Collins, II,W. S., Schrider, jun., C. T., and Akeroyd, J. H., Transfusion, 2, 100 (1962).

'Huntsman, R. G., Hurn, B. A. L., Ikin, E. W., Lehman, H., and Liddell, J., Brit. Med. J., 1508 (1962).

Cushing, J. E., Ridgway, G. J., and Durall, G. L., Biol. Bull., 113, 343 (1957).

- Lovelock, J. I., and Bishop, M. W. H., Nature, 183, 1394 (1959).

'Ashwood-Smith, M. J., Nature, 190, 1204 (1961).

- Dougherty, R. M., Nature, 193, 550 (1962).

- Porterfield, J. S., and Ashwood-Smith, M. J., Nature, 193, 548 (1962).

${ }^{10}$ Perry, V. P., Fed. Proc., 22, 102 (1963).

${ }^{11}$ Greaves, R. I. N., Nagington, J., and Kellaway, T. D., Fed. Proc., 22, $90(1963)$

${ }^{12}$ Huggins, C. E., Science, 139, 504 (1963).

\section{A New Anti-Ag Serum (L. L.)}

Is 1961 Allison and Blur iberg described genetically determined low-density $\beta$-lipoprotein differences in human sera revealed by means of a gel-diffusion technique, where about 60 per cent of U.S. white sera formed precipitates with serum from a repeatedly transfused patient (C. de B. $)^{1-3}$. The new system was called the Ag-system and the two types of human sera revealed by the antiserum C. de B. were called $\mathrm{Ag}(\mathrm{a}+)$ (reactors) and $\mathrm{Ag}(\mathrm{a}-)$ (non-reactors). In 1963, Blumberg and Riddell described a second antiserum (the New York antiserum I. M.) reacting with about 97 per cent of U.S. white sera ${ }^{3}$. Sera forming precipitates with the $I$. M. antiserum were denoted as $\mathrm{Ag}(\mathrm{b}+)$, non-reactors as $\mathrm{Ag}(\mathrm{b}-)^{3}$. Recently, Bundschuh et al.4 described another anti-Ag serum reacting with about 65 per cent of sera from individuals living in Berlin (D.D.R.).

Blumberg and Riddell have stated that they have found more than 20 "human antihuman serum protein antisera" revealing at least seven different $\beta$-lipoprotein specificities ${ }^{3}$, but to our knowledge these further antisera have not yet been described in detail.

Another anti-Ag serum (L. L.) was found among 24 sera from repeatedly transfused patients with coagulation defects. The patient L. L. suffers from hæmophilia A and has had more than 300 blood and plasma transfusions. In a sample consisting of 136 sera from unrelated adult Swedes living in Stockholm, 51 (37.5 per cent) were found to give strong precipitates with L. L. whereas $85(62.5$ per cent) were non-reactors. No other reaction types such as weak precipitate formation ${ }^{1,2}$, the formation of more than one precipitin $\operatorname{line}^{2,4}$ or other qualitative differences, for example, in the concavity of the precipitin $l_{i n} e^{2}$ has been found when fresh sera were investigated.
In sera which had been stored for a longer time, the precipitates were, however, sometimes weak. Forty-eight of the 136 sera were collected one month before the investigation started and special care was taken to avoid ageing of these sera which were kept at $-20^{\circ} \mathrm{C}$ immediately after their collection. Here the frequency of reactors against L. L. was 43.8 per cent.

Through the kindness of Drs. Allison and Blumberg, one of us (J. H.) received a generous sample of antiserum C. de B. Comparison of the two sera showed that antiserum L. L. has another specificity than C. de B. in that it only reacts with some, but not all, sera giving precipitate formation with $\mathrm{C}$. de $\mathbf{B}$. ( $\mathrm{Ag}(\mathrm{a}+))$ and so far has been found to react with no sera belonging to type $\mathrm{Ag}(\mathrm{a}-)$ (non-reactors against C. de B.) (Table 1).

Nor does the serum appear to be identical with the antiserum I. M. because it does not give two precipitin lines when reacted against C. de B. as does the antiserum I. M. (ref. 3). In addition the percentage of reactors is only 37.5 per cent in our material when $L$. $L$. is used as compared to 97 per cent when the serum I. M. was tested on sera from New York whites ${ }^{3}$.

Table 1. Reaction Patterns of C. DE B. and L. L. Against 72 SERA Table 1. Reaction PATTERNS OF C. DE B, and L. L.

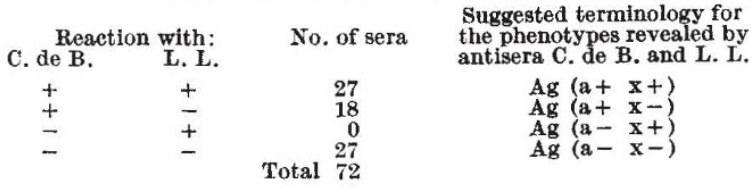

Family studies on 32 families with 101 children show that the antigen revealed by $\mathrm{L}$. L. is genetically controlled. All 36 children in 12 matings, where both parents were non-reactors against L. L., were also non-reactors.

Due to the fact that the antigen demonstrated by the antiserum L. L. has so far only been found in sera which are also reactors against C. do B., it was thought that a close relation exists between the antigens revealed by C. de B. and L. L. similar, for example, to the Gm a and $\mathrm{Gm} \times$ antigens, where the $\mathrm{Gm} \times$ antigen rarely occurs in sera which are $\mathrm{Gm}\left(\mathrm{a}_{-}-\right)$. It was therefore suggested that sera reacting with $L$. L. are to be denoted $\mathrm{Ag}(\mathrm{x}+)$ and non-reactors against L. L. Ag $(x-)$. The nomenclature for the four possible major phenotypes revealed by serum C. de B. and L. L. is given in Table 1 using the term Ag a in the sense of Allison and Blumberg (all sera reacting with C. de B. are denoted as Ag $(a+))$.

Evidence to be presented elsewhere ${ }^{5,6}$ (for example, absorption experiments of C. de B. with $\mathrm{Ag}(\mathrm{a}+\mathrm{x}-)$ sera, reactions of partial identity between $\mathrm{Ag}(\mathrm{a}+\mathrm{x}+)$ sera and $\mathrm{Ag}(\mathrm{a}+\mathrm{x}-)$ sera against unabsorbed C. de $\mathrm{B}$. serum) indicates, however, that antibodies against the $\mathrm{Ag} \times \mathrm{x}$ antigen do also occur in serum C. de B. On account of other evidence (for example, the appearance of two precipitin lines when certain sera are reacted against C. de B. ${ }^{2}$ ) Allison and Blumberg have already postulated the existence of antibodies against two different antigens in C. de B. The evidence found by one of us (J. H.) does consequently lend further support to their theory.

JAN HIRSCHFELD

State Institute of Blood Group Serology,

Statens Rättskemiska Laboratorium, Stockholm 60.

\section{Margareta BlombäcK}

Coagulation Research Department, Karolinska Institutet, Stockholm 60.

${ }^{1}$ Allison, A. C., and Blumberg, B. S., Lancet, i, 634 (1961), ${ }^{2}$ Blumberg, B. S., Bernanke, D., and Allison, A. C., J. Clin. Invest., 41,

3 Blumberg, B. S., and Riddell, N. M., J. Clin. Invest., 12, 867 (1963).

- Bundschnh, G., Geserick, G., Marek, Z., and Fünfhausen, G., Das Deutsch. Gesdwes., 18, 819 (1963).

6 Hirschfeld, J., Science Tools (in the press)

- Hirsehfeld, J., Blumberg, B. S., and Allison, A. C. (to be published). 